\title{
LEÓN DE GREIFF EN EL CONTEXTO DE LA VANGUARDIA COLOMBIANA (1895-1976)
}

\author{
María M. Caballero \\ Universidad de Sevilla
}

«Irónico y sentimental, pagano y místico, cosmopolita y terrígena, trascendente y burlador, árido y abundoso, León de Greiff, producto singular de un raro cruce de sangre y de culturas, se alza sobre el panorama de la literatura americana como un esbelto monolito, todo esculpido de símbolos y alegorías» ${ }^{1}$. Su poesía revela como pocas la intención de permanecer tenazmente recluído en su propio yo sin integrar, ni menos aún crear, escuela alguna. Su acento está a salvo de cualquier imitación.

Es un hecho notorio que su obra no se ha difundido entre el público colombiano e hispanoamericano, a pesar del parcial reconocimiento de la crítica en los últimos años. Señalado ya desde 1915 como vanguardista por su vinculación al grupo Panida de Medellín, desconcertaba al lector medio por su tono radicalmente diferente al de la lírica colombiana del momento. Uno de los primeros en percibirlo fue el crítico Hernando Téllez, compañero de generación, quien cifraba su valía en la originalidad: «en Latinoamérica — decía el catorce de Enero de 1950— no hay nada en poesía que se parezca a la suya» ${ }^{2}$. Desconocido, incomprendido y combatido de 1915 a 1930 por la crítica oficial colombiana, comienza a ser incorporado en las décadas siguientes a historias y antologías como un elemento extraño e inclasificable. En cuanto al ámbito de la literatura hispanoamericana, el panorama es casi desolador: Torres Rioseco (1951) ni lo cita; Pedro Henríquez Ureña se limita a recoger su nombre y fecha de nacimiento en Las corrientes literarias en la América Hispánica (1949) ${ }^{3}$; Enrique Anderson Imbert lo incluye en

1 MAYA, Rafael: Obra crítica. Tomo II. Bogotá, ed. Banco de la República, 1982, pág. 219.

2 TELlEZ, Hernando: Los Nuevos (en Semana. Bogotá, núm. 169, vol. 8, 14 de Enero de 1950).

3 HENRÍQUEZ UREÑA, Pedro: Las corrientes literarias en la América Hispánica. México, FCE, 1966, pág. 266. 
el grupo de «los raros», especie de cajón de sastre en el que se inscriben algunos vanguardistas ${ }^{4}$.

La reivindicación de su figura partirá del contexto colombiano. Fue Baldomero Sanín Cano, cosmopolita cuya labor crítica puede equipararse a la de Valera en España, quien llamó la atención sobre el nuevo valor en su ensayo acerca de Variaciones alredor de nada, publicado el treinta de Enero de 1937 en La Defensa, de Medellín. Un año después Juan Felipe Toruño en Los desterrados de El Salvador, plasma con acierto las peculiaridades de la mejor actuación degreiffiana:

«Para mi, León de Greiff descuella en el grupo de los musicales por su delicadeza combinativa, por su acusticidad, por su metaforismo en el desenvolvimiento de lo que denomino óperas sintéticas — síntesis de vida - con un desplegar de conceptos, con verbalismos plenamente castizos, con ciertos neologismos entresacados de etimologías, con conocimiento del material que emplea en sus construcciones» ${ }^{5}$.

Con este texto se ponen los cimientos para la exégesis profunda de una de las estéticas más complejas de nuestro tiempo. Aún así habrá que esperar unos años para encontrar trabajos críticos de más enjundia, como los de Rafael Maya y Jorge Zalamea ${ }^{6}$, que comparten inicialmente su aventura poética, completándola con labores ensayísticas; y Fernando Charry-Lara ${ }^{7}$, algo más joven que los anteriores pero situado en la misma tesitura a caballo entre la crítica y la creación literarias. Finalmente las tesis doctorales de Orlando Rodríguez Sardiñas ${ }^{8}$ y Stephen Mohler ${ }^{9}$ realizadas en los Estados Unidos atestiguan el interés por uno de los poetas colombianos más originales del siglo XX. Es significativo, en la misma línea, el sustancioso párrafo que le dedica la última Historia de la Literatura Hispanoamericana publicada en España ${ }^{10}$.

Tanto la vida como la creación literaria de León de Greiff están llenas de paradojas; y así sucede que su revalorización actual incluso el hecho de ser «el más popular de los poetas mayores de Colombia» ${ }^{11}$, no supone en absoluto que

4 ANDERSON IMBERT, Enrique: Historia de la Literatura Hispanoamericana. Tomo II. México, FCE, 1974, págs. 14, 15, 44-45, 191.

5 TORUÑO, Juan Felipe: Los desterrados. El salvador, 1938, pág. 32. Posteriormente ha ampliado sus opiniones en otro trabajo: Sinfonismo en la poesía de León de Greiff (en Revista de la Universidad de Antioquía. Medellín, Abr.-May., 1943, págs. 265-272).

6 ZALAMEA, Jorge:Prólogo a Obras completas de León de Greiff. Bogotá, Ed. Tercer Mundo, 1975). Esta es la edición más completa del colombiano y, por tanto, la que hemos utilizado aquí.

7 CHARRY-LARA, Fernando: los poetas de «Los Nuevos» (en Revista Iberoamericana. Pittsburgh, núms. 118-119, Jul-Dic., 1984, págs. 633-681).

8 RODRÍGUEZ SARDINAS, Orlando: León de Greiff, una poética de vanguardia. Madrid, Playor, col. Nova-Scholar, 1975.

9 MOHLER, Stephen: El estilo poético de León de Greiff. Bogotá, Ed. Tercer Mundo, 1975. Conviene advertir que hasta el momento, éstos son los trabajos más serios sobre León de Greiff, quien ha sufrido una avalancha bio-bibliográfica de tono ponderativo y laudatorio, de escaso interés.

10 BELLINI, Giusseppe: Historia de la Literatura Hispanoamericana. Madrid, Castalia, 1985, págs. 408-409).

11 ZALAMEA, Jorge: Op. cit., pág. IX. 
sea leído ni comprendido por el lector medio. Sigue siendo un «raro», como diría Rubén Darío de ciertos autores esotéricos del siglo XIX. Sus claves poéticas le convierten en un producto irrepetible en el panorama de la lírica contemporánea... La singularidad de su estilo se debe a su gran afinidad con la música sinfónica, combinada con un fuerte deseo de libertad personal, aventuras nocturnas y autoexploración psicológica. La música campea en todos los aspectos de su poesía —contenido, estructura e imágenes - hasta el punto de sobrepasar a los simbolistas y modernistas más extremados. Es, en realidad, un compositor cuyos instrumentos son palabras. La estructura de muchos de sus poemas se inspira en formas de la música clásica — suite, rapsodia, nocturna, fuga, sonata... - con preferencia por las más libres e imaginativas. La modulación rítmica adquiere sentido primordial y a su servicio están onomatopeya, aliteración e incluso variaciones léxicas... En ocasiones, el tono del poema viene sugerido por el uso de terminologías musical en el título. Los sonidos, el viento e incluso el silencio nocturno inciden en la imaginación del poeta orquestándola instrumentalmente como una inmensa ópera, en la que se diluye el yo degreiffiano. Las referencias a sus compositores favoritos —Chopin, Mussorgsky, Schubert, Bethoven y algunos más...- matizan de cara al lector este mundo rico en sugerencias estéticas. Los vocablos insinuantes, volubles y melodiosos, sólo se conciben en el aire de sus poemas, en ese «mundo sonoroso» del que habla Rodríguez Sardiñas.

Su buen gusto artístico y su maestría técnica se plasman en los experimentos en versificación y en la riqueza y variedad de su vocabulario. Porque León de Greiff es, ante todo, el creador de un lenguaje poético. Su capacidad de construcción idiomática se patentiza en esa «ardua y heterogénea opulencia de la palabra» ${ }^{12}$. De ahí que convivan formalmente la expresión culta y el habla coloquial; el arcaismo y el neologismo; las voces extranjeras y aquellas de propia invención. De «malabarismos idiomáticos» califican algunos de sus críticos estos divertimentos con que el colombiano demuestra su posesión y goce del idioma, y que conectan con el sentido de experimentación lingüística característico de todo un sector de la literatura contemporánea: Joyce, Huidobro...

Una de las cualidades más dinámicas de la personalidad del poeta es el deseo irrefrenable de expresar la libertad personal. Se libera de los confines de la vida cotidiana por medio de la fantasía; de los límites de los sentidos por la vía de la sinestesia; y de la lógica por medio de constantes paradojas, conectadas con un simbolismo intuitivo. El esguince humorístico es en León de Greiff la constante autoironía de un espíritu voluntariamente antirromántico en la idea y anticlásico en la forma, elegida con singular precocidad. «De Greiff es el romántico sin par en tierras colombianas» — dice Carlos García Prada ${ }^{13}$-; y pienso que su afirmación no es descabellada ya que lo mejor del espíritu romántico subyace y pervive en el modernismo y en la lírica contemporánea. Pero, además, como en cualquier irónico, hay en el colombiano un sensitivo incorregible. Sólo que las energías disolventes de su espíritu están alerta para sofocar cualquier rebelión del sen-

12 CHARRY-LARA, Fernando: Op. cit., paǵ. 664.

13 GARCÍA PRADA, Carlos: Estudios Hispanoamericanos. México, 1945, pág. 232. 
timiento. De ahí proceden los bruscos contrastes y transiciones de su poesía, reflejo de un aparente sentido humorístico de la vida. En el fondo ocultan, no solo la irremediable dolencia de un espíritu desengañado, sino también el pudor de una sensibilidad extrema, combinada con cierta timidez temperamental.

La actitud autoburlesca y ese tono de provocación y autodefensa respecto de los críticos le lleva a designar sus creaciones como «mamotretos». En rigor, el término «mamotreto» describe un volumen de abundantes trabajos literarios, acumulados sin organización ni selección aparentes. Sus Obras completas (Medellín 1960) recogen siete, en los que alterna lírica y prosa poética. Si a ello agregamos Nova et vetera, Vieja y novísima y algunos otros fascículos y poemillas dispersos, nos enfrentamos a un voluminoso, mamotrético corpus verbal que ha ido creciendo incontenible con el paso de los años ${ }^{14}$. El elemento aglutinante de este vasto maremagnum es el sujeto. De Greiff es uno de los poetas más introspectivos que se conocen; pero a pesar de eventuales declaraciones en que confiesa: «mi vida toda está en mis libros» ${ }^{15}$, nada sabemos directamente por ellos de lo apariencial, las peripecias sentimentales, las angustias de la vida cotidiana. Su yo, omnipresente y esquivo, se desdobla mediante «las multánimes almas que hay en mí» (Tergiversaciones, OC, pág. 21) en variopintas encarnaciones, máscaras que no recubren sino potencian las distintas personalidades del poeta: Leo Legris, Matias Aldecoa, Gaspar von der Nacht, Erik Fjordsson, Sergio Stepansky, Claudio Monteflavo, Ramón Antigua, Lope de Aguinaga, Diego de Stúñiga, Hárald el Oscuro, Guillaume de Lorges, Miguel Zulaíbar, El Skalde... y varios más constituyen ese «consorcio poético» del que habla Zalamea. No son simples seudónimos, sino que cobran vida propia, atribuyéndose vertientes complementarias de la autobiografía de-greiffiana que integra en el yo ontológico, tanto la anecdótica aventura cotidiana, como lo que alguna vez pensó, soñó o sintió: trasunto de formas culturales, historia, poesía, música, leyenda y mitos... Es su testamento, su legado, fruto de una larga y fecunda existencia, de una imaginación exhuberante y una potencia verbal arrolladora.

Quizás su raíz nórdica que aflora a la superficie una y otra vez sugiriéndole acentos teñidos de nostalgia y arrogancia, pueda explicar parcialmente la pluralidad de facetas de su poesía y persona. Nace en Medellín, el veintidós de Julio de 1895, en el seno de una familia de alemanes y eslavos asentados en Antioquía desde mediados del XIX. Se educa en el fragor de los ecos del rezagado modernismo colombiano, uno de cuyos exponentes, Porfirio Barba Jacob, es también antioqueño. Compagina tres años de estudios en la Escuela de Minas de Medellín, con el ejercicio poético que va absorviendo progresivamente su interés, hasta el punto de que en 1915 funda la revista Panida, órgano expresivo de un grupo del mismo nombre constituído por trece escritores y artistas amigos. Entre ellos destacan por su repercusión posterior: Fernando González, Félix Mejía Arango

14 Desde mi punto de vista ese carácter «mamotrético» ha perjudicado la obra del colombiano. A de Greiff le falta selección, una autocrítica continuada... Parece que publica todo, y su poesía se resiente de ello.

15 SERNA GÓMEZ, Jaime: León de Greiff: su vida. Selección de sus poesías. Medellín, Ed. Salesianas, 1973, pág. 41. 
y Rafael Jaramillo Arango... En Panida y con el entusiasmo combativo de los escritores de la modernidad publica su primer poema, escrito en 1914: La balada de los buhos extáticos. La referencia al contexto literario del momento que había trocado el exotismo del «cisne de engañoso plumaje» por la mirada inquisitiva del sapiente buho «que interpreta el misterioso libro del silencio nocturno» en Darío y Enrique González Martínez; se completa con un mundo lunar, deudor de Lugones y Laforgue en el que resuenan los ecos de una «trova paralela / trova unánime y sorda, extraña cantinela / que coloquian los buhos ordenados en fila» (Tergiversaciones, OC, pág. 28). La conversión de los buhos en instrumentos musicales, la incidencia en el ritmo mediante rimas paralelas y el insistente estribillo, permiten apreciar ya una personalidad acusada en el joven escritor.

Las primeras poesías del colombiano que escapan al estrecho marco medellinense se publican en Voces, revista de Barranquilla que, entre 1917 y 1920 marca el tono más avanzado de la anquilosada lírica del país. Su animador fue Ramón Vinyes, el librero catalán de Cien años de soledad, hombre de gran cultura y perspicacia literaria que por medio de sus traducciones difundió las novedades europeas y norteamericanas, ofreciendo así una dinámica alternativa a las mortecinas revistas nacionales. Su agudeza le llevó a ver un futuro valor en el «muchacho exagerado, con rasgos de genio y aislamiento de místico en la literatura (que) nunca llora ni grita (sino que) sonríe siempre; nunca ríe. Y ríe de todo, para sí. Es el más original entre todos los de la nueva generación» ${ }^{16}$. Vinyes fue estímulo indudable para el romántico afán de originalidad del joven de Greiff, deudor de individualismo nietzschiano imperante en la literatura antioqueña del momento ${ }^{17}$. No deja de ser curioso que en el número 1 de Voces, de diez de Agosto de 1917, dé a conocer el Gaspar de la Nuit de Aloysius Bertrand, que se convertirá en el principal alter-ego degreiffiano, el que escribe su biografía en prosa poética - Prosas de Gaspar-. La dedicatoria de un Ritmo en 1921 (Tergiversaciones, OC, pág. 80) es homenaje obligado a un hombre que tradujo y publicó en el número cuarenta y dos de la revista los primeros textos de la vanguardia europea; y que a su vuelta de España como exiliado en 1940 realizará una labor semejante en la revista Crónica (1950-1951), órgano expresivo de varios periodistas que contituyen el Grupo de Barranquilla y entre los que se encuentran Alvaro Cepeda Samudio, Germán Vargas y Gabriel García Márquez ${ }^{18}$.

16 Así se expresa en la introducción al número 19-20, dedicado a la literatura antioqueña, con colaboraciones de Abel Farina, José Restrepo Rivera y otros... La conexión con la revista costeña se explica por la presencia en Medellín por esos años del filósofo barranquillano Julio Enrique Blanco, colaborador de Voces. León de Greiff envía bajo seudónimo de «Leo Legris» varios sonetos, rondeles, músicas... que aparecerán en los números 32, 40 y 48, respectivamente (1918-19). El número 56, de veinte de Febrero de 1920 le está dedicado casi en su totalidad. Cfr. Voces, 1917-1920. Selección de Textos. Bogotá, Instituto Colombiano de Cultura, 1977.

17 Cfr. RESTREPO, Enrique: La influencia de Federico Nietzsche en las generaciones jovenes de Antioquía (en Ibídem, paǵs. 221-237).

18 Cfr. MEDINA, Alvaro: Don Ramón, el maestro catalán de «Cien años de soledad». (en Revista La Pluma. Bogotá, Nov. 1975; y GILARD, Jacques: El grupo de Barranquilla. (en Revista Iberoamericana. Pittsburgh, números 128-129, Jul.-Dic. 1984, págs. 905-935). 
Después de conseguir la fama local que era posible a un «panida» de Medellín, años de anonimato en Bogotá, donde trabaja como secretario del general Rafael Uribe Uribe en 1923, tres meses antes de su asesinato... La estela de violencia en que se debatía el país por los continuos enfrentamientos entre liberales y conservadores que provocaron hasta nueve guerras civiles en el XIX, culminando en la guerra de los mil días, no afecta a su obra poética. Y es que, a tono con la profesionalización del escritor a partir del modernismo, lo cotidiano de su existencia se nutre de variadas ocupaciones que no tiene que ver con la lírica: trabajó en el Banco Central de Bogotá; en la construcción del ferrocarril troncal de Occidente en Bolombolo entre 1925 y 1927. De ahí pasó a la dirección del Departamento de Caminos (1927-1931) y entre 1931 y 1945 permaneció en el Consejo Administrativo de los Ferrocarriles Nacionales como Jefe de Estadística. Posteriormente estuvo conectado con el Ministerio de Educación Nacional como Jefe de Extensión Cultural, y con la Universidad Nacional de Colombia como profesor de Literatura e Historia de la Música. De modo esporádico desempeñó las funciones de Encargado de Negocios de la embajada de Colombia en Suecia; y a finales del sesentayocho fue elegido miembro de número de la Academia Colombiana de la Lengua. Musicólogo, ajedrecista, experto en crucigramas, aficionado al álgebra, se acerca intelectualmente a los más eximios simbolistas y herméticos franceses, como Valery y Mallarmé, que también buscaron secretas afinidades entre matemática y poesía.

Cuando León de Greiff llega a Bogotá, Colombia ya no era la república literaria de años anteriores, con ministros poetas y presidentes humanistas. Empezaba la llamada República Financiera; llegaban los millones de la indemnización americana por la cuestión de Panamá; se abrían caminos, se construían carreteras; la instrucción tomaba nuevos rumbos orientándose hacia el estudio de las ciencias económicas y sociales. El universitario, rota la costra provinciana, se agrupaba en gremios beligerantes, buscando conexión con las asociaciones afines del exterior... El tipo de colombiano erudito, científico y letrado, quedó prácticamente fuera de la órbita oficial, excluído de los cargos administrativos; y entraron a dominar el comerciante y el financiero, protagonistas de la cultura técnica e industrial que avanzaba sobre la ruina del persistente humanismo.

En el campo más específico de la literatura, la renovación modernista daba sus últimos coletazos. Había tenido un precursor en José Asunción Silva; y un poeta que la realiza en toda su plenitud, Guillermo Valencia. Silva entró en contacto, a pesar de su corta vida, con los más importantes simbolistas que aleteaban por debajo de las futuras vanguardias. Hacia 1884-1886 vivió entre Londres, $\mathrm{Pa}$ rís y Ginebra; y conviene recordar que el manifiesto de los simbolistas de Jean Moreas se publicó en 1886. Además, la teoría simbolista se había difundido antes en varios escritos: Poemas saturniens (1866) de Verlaine; Une saison en enfer (1873) de Rimbaud; L'apres-midi d'une faune (1876) de Mallarmé y Les complaintes (1885), de Jules Laforgue. La predilección de José A. Silva por Baudelaire, Verlaine y Mallarmé y el profundo conocimiento de Edgar A. Poe lo sitúan en la encrucijada precisa, a nivel de lucha con el lenguaje y disparo de la sensibilidad, que producirá los movimientos artísticos del XX; y como precedente inmediato de León de Greiff, a pesar de lo dispar de sus personalidades. 
De entre los modernistas colombianos es Guillermo Valencia el poeta de insuperable maestría formal, sobrio y culto, de melancolíca elegancia y mayor sentido de la plasticidad. En sus Ritos (1898) marcados por el parnasianismo, triunfa una brillante concepción arquitectónica del poema heredada de Grecia y que influye poderosamente en la generación siguiente, la del Centenario. Esta se da a conocer en torno a 1910, fecha del centenario de la independencia americana; y en realidad, más que un grupo abanderado bajo una consigna particular, representaba — según Armando Romero ${ }^{19}$ — la «inteligencia» colombiana de la época. Se habían propuesto armonizar la civilización política y cultural con el futuro desarrollo del país, tratando de conseguir un sincretismo pacífico; y a ejemplo de Valencia, -importante figura de la política nacional, jefe de partido, orador parlamentario y candidato dos veces a la presidencia del país se comprometieron en la vida pública hasta el punto de configurar su fisionomía. Destacan entre ellos los liberales Alfonso López y Eduardo Santos, y el conservador Laureano Gómez; todos presidentes coiombianos. El ámbito en que se mueven determina que se vieran afectados por el peor modernismo, salvo honrosas excepciones entre las que se cuenta Eduardo Castillo, poeta de gran cultura y rara sensibilidad, mezcla de romántico y simbolista; y José E. Rivera quien tres años antes de derramarse poéticamente en su novela La vorágine (1924) publicó Tierra de promisión, conjunto de sonetos definidos por el modo subjetivo y lírico de presentar la vida del trópico.

Ya en 1918 en una conferencia pronunciada en Bogotá sobre los jóvenes poetas colombianos, Eduardo Castillo apuntaba en ellos nuevos aires propicios al cambio; señalando a Rafael Maya y León de Greiff como figuras señeras de la renovación. Hablando del segundo decía:

«Se trata, pues, de un artista contradictorio y paradójico y a veces extravagante y absurdo que escapa a todo intento de captación crítica, a toda tentativa para abarcar los diversos aspectos y modalidades de su talento» ${ }^{20}$.

Sus palabras pueden considerarse el traspaso de la antorcha generacional a un nuevo grupo, el de los nacidos entre 1894 y 1908, que alcanza notoriedad en la escena literaria sobre 1924 y con el que irrumpe la vanguardia. En general, los vanguardistas «hacen hincapié en la poesía como fenómeno histórico, como devenir y no como ser. Para ellos los poetas se dividen, no en malos y buenos, sino en viejos y nuevos. Bueno es ser poeta nuevo, mejor todavía es ser poeta novísimo, palabra predilecta de los críticos de la época» ${ }^{21}$. Ello explica el nombre del grupo que surge ahora en Colombia, los Nuevos, en torno a una revista del mismo nombre aparecida en Bogotá el seis de Junio de 1925 y de efímera existencia

19 ROMERO, Armando: Las vanguardias en Colombia. (en Revista Iberoamericana, Pittsburgh, números 118-119, Ene-Jun. 1982, págs. 275-287).

20 CASTIllo, Eduardo: Tinta perdida. Bogotá, Ed. del Ministerio de Educación, 1965, págs. 121-122.

21 BARY, David: En torno a las polémicas de vanguardia. (en Movimientos de vanguardia en Hispanoamérica. Memoria del Undécimo Congreso de la Revista Iberoamericana, celebrado del 29 al 31 de Agosto de 1963. México, 1965, Universidad de Texas, pág. 25). 
(seis números), como era habitual en la vanguardia. Su director, Alberto Lleras Camargo, realizó en 1976 una de las más vivaces evocaciones del ambiente; habla de dos cafés bogotanos, el Windsor de la calle treinta y dos, y el Rivière en la veinticuatro, sitios habituales de las tertulias. Allí iba de Greiff:

«con el sombrero gigante de amplias alas, la barba bermeja e hirsuta, los ojos azules de vikingo - que no habían visto el mar-y la pipa, que echaba humo perfumado sobre las ondas humanas, como la chimenea de un barco fantasmagórico. Allí concurría Ricardo Rendón, que llegaría a la celebridad como primer caricaturista político en la historia del país, y que influyó considerablemente en el desplome de la ideología conservadora de 1930: silencioso y vestido de negro, borroneando dibujos sobre la blanca mesa metálica. Luis Tejada, muy joven, un poco frágil, despeinado, curioso, parecía salir a la calle a capturar imágenes que, después, una a una, iban apareciendo en sus crónicas escritas en un estilo de simplicidad y firmeza que recordaba la línea en los dibujos de Rendón, en abierta contradicción con los principios retóricos de la época. Y el también joven poeta Luis Vidales. Y Jorge Zalamea, locuaz y divergente y contradictor a todas horas. Y el melancólico José Mar, ya pronto escribiendo sin tregua, en prosa tersa, la nota editorial de los periódicos liberales» ${ }^{22}$...

A través de estas apretadas líneas puede percibirse la heterogeneidad del grupo. Quizá la obra de sus mejores prosistas (Jorge Zalamea, Germán Arciniegas, Lleras Camargo, Hernándo Téllez y Eduardo Zalamea Borda) acoja innovaciones de la literatura francesa, inglesa y norteamericana, con mayor entusiasmo que la de sus poetas... En general, la diplomacia, el poder y la política alejaron a algunos de la creación literaria, hasta el punto de acabar captados por los centenaristas, de cuyas doctrinas habían sido furibundos detractores. Esta curiosa asimilación lleva a Jorge Zalamea a cuestionar la labor literaria de Los Nuevos presentándola como «una actividad de prestado, una válvula de escape de la que había sido faćil apoderarse por la misma miseria de nuestra literatura... y en la que pasado el tiempo se decantarían cuatro o cinco escritores auténticos, artistas de vocación insobornable» ${ }^{23}$. Sus palabras, parcialmente justificadas, denotan la autofagia en que desemboca la actitud polémica del grupo respecto del quehacer de las letras patrias ${ }^{24}$.

Hay que reconocer que la literatura colombiana estaba imbuída por cierto tono grecolatino, derivado tanto del modernismo - Darío y Valencia-, como de las remotas humanidades del XIX - Rufino José Cuervo y Miguel A. Caro-. Este grecolatinismo y los últimos coletazos modernistas alcanzan todavía a la facción de Los Nuevos que representa en política la tendencia conservadora tradicional: Silvio Villegas, José Camacho Carreño, Eliseo Arango y al mismo Rafael Maya, quien detecta el fenómeno en sus Consideraciones críticas sobre la litera-

22 Recogido por Fernando Charry-Lara, op. cit., pág. 639.

23 Ibídem, pág. 650.

24 Abundan, en este mismo sentido, las declaraciones de Hernando Téllez sobre la irresistible tendencia a la cursillería de los centenaristas, o la irracionalidad, monotonía y confusión de los escritores de Piedra y Cielo, cuya oscuridad ataca airadamente en 1940 otro compañero de generación, Juan Lozano y Lozano... 
tura colombiana (1944) ${ }^{25}$. A ello se suma el constante aislamiento del país, propulsor de un tipo de literatura provinciana, en la que se refleja — decía Maya«un buen sentido nacional que rechaza lo extravagante y arbitrario». Por eso, las tendencias vanguardistas europeas que en algunos lugares serán particularmente ruidosas, tuvieron en Colombia una mínima repercusión. ¿Tal vez porque fueron conocidas fragmentaria y posteriormente, como afirma Rafael Gutiérrez Girardot? ${ }^{26}$. Ello equivaldría suponerlas desarrollo dialéctico del modernismo endógeno. Al respecto, valdría la pena recordar la declaración de Luis Vidales de que cuando escribió sus poemas de Suenan timbres (1926) no había leído a los autores más representativos de la vanguardia francesa. Y conviene advertir del alcance de tal confesión ya que este libro de Vidales, por sus audacias métricas y el soterrado humorismo que le llega de Luis Carlos López —el postmodernista colombiano que canta la provincia-, es considerado junto a Tergiversaciones (1925) de León de Greiff el primer monumento del «vanguardismo» colombiano.

Tergiversaciones (Bogotá 1925) recoge lo mejor de la producción degreiffiana entre 1915 y 1922. Temática y formalmente adelanta la heterogeneidad de los mamotretos del colombiano: sonetos, baladas, rondeles, arietas y estampas... con ese sentido de «obra abierta», que se completará en sucesivas entregas, con la connivencia del lector al que se implica en el juego.

Se advierten asimismo, en esta primera colección poética, las fluctuaciones del autor con afán de originalidad, que se enraiza en una tradición y todavía no ha terminado de «cuajar» un estilo propio. Su tono es desigual: desde ecos juanramonianos en: «mi pobre amor se está yendo / yo me quedaré llorando» (Tergiversaciones, OC, pág. 62); hasta la huella de esa lírica galante, versallesca y exótica, poblada de frívolas hermosas que cultivaron Gutiérrez Nájera y cierto Darío: «en la alameda / de ese jardín / canta el violín / con voz de seda; / de la arboleda / por el confín / parla en latín / el Cisne a Leda... / Más cerca -loca / por el Abate- / Clorinda cede... / cede su boca... / Breve combate. / Todo se puede»... (Tergiversaciones, OC, pág. 24). Sin olvidar versos sutiles del tipo: «ya se fina la tarde opalescente»... (Tergiversaciones, OC, pág. 21) que remiten a un mundo crepuscular procedente de Samain, y conectan con Los parques abandonados (1910), de Herrera y Reissig y los simbólicos atardeceres de Crepúsculos del jardín (1905), de Lugones.

El poeta se va despojando progresivamente de ese lastre inicial de resabios modernistas, en su deseo de adquirir un estilo propio... Dejando de lado a sus compatriotas hispanoamericanos va a beber directamente a las fuentes francesas, los simbolistas y sus precursores Baudelaire, Gérard de Nerval y Lautreamont. Baudelaire, en su famoso soneto Correspondences (1857) plasmó el programa simbolista cuyo eje formal es la analogía entre lo que perciben los sentidos y lo que sabemos misterioso e inalcanzable. "Baudelaire hizo de la analogía el centro de su poética. Un centro en perpetua oscilación, sacudido siempre por la ironía, la

25 Cfr. MAYA, Rafael: Op. cit., pág. 208.

26 Recogido por Fernando CHARRY-LARA, op. cit., pág. 649. 
conciencia de la muerte y la noción del pecado» ${ }^{27}$. Para Baudelaire, el sistema del universo es el modelo de la creación poética: es un lenguaje cifrado en continuo y vertiginoso movimiento y cuyo traductor es el poeta. León de Greiff se inscribe en esa tónica el incluir seis poemas bajo la rúbrica Correspondencias. Elijo uno al azar:

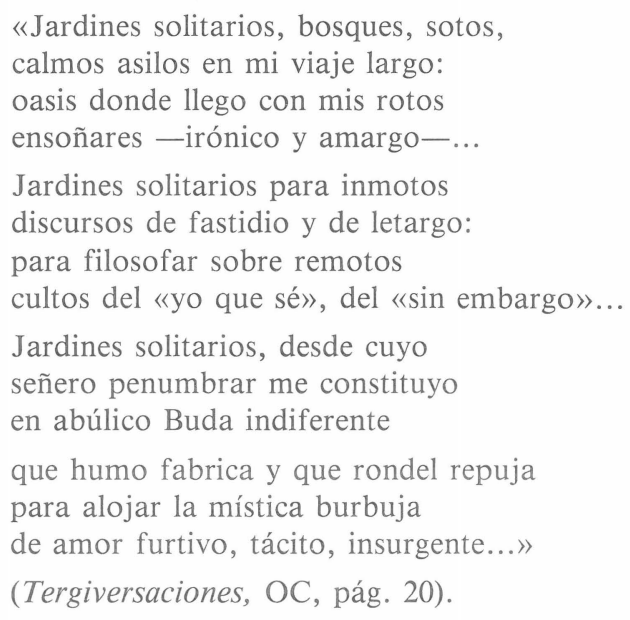

$\mathrm{Al}$ releer entre líneas, destacan elementos estrictamente relacionados con la cosmovisión baudelairiana: el viaje - puerta abierta a la ensoñación y la fantasía, que permite escapar del fastidio cotidiano, es trasunto de L'invitation au voyage de Petits poémes en prose (1868), varios de cuyos pasajes cita de Greiff en Preludio en re mayor (Libro de Signos, OC, pág. 232). El poeta -trovero, juglar, loco... al que la sociedad relega - es ese albatros tan fuerte y garboso en el vuelo (poesía) como torpe y desmañado en tierra (vida); sus inmensas alas, al enfangarse le impiden volar. Baudelaire escribió en muchos de sus poemas sobre su frustado escape del abismo de la vida en busca del ideal, asociando la altitud con la superioridad espiritual y la caída de Icaro con el fracaso... En el soneto transcrito, al truncarse al ensoñación, el poeta se despeña cual nuevo Ícaro, hacia la realidad cotidiana definida por semas opuestos al movimiento: inmoto, fastidio, letargo, indiferencia, abulia, Buda... De todos, fastidio y aburrimiento transparentan l'ennui y le spleen que configuran toda una sección de Les fleurs du mal (1857). De Greiff escribió en la misma vena La balada del aburrimiento perenne (Tergiversaciones, OC, pág. 44); Arietas (Tergiversaciones, OC, paǵ. 71) y Ritmos (Tergiversaciones, OC, pág. 84). Su identificación con ese Buda apático, que fuma la pipa como un buho - Les hihboux de Baudelaire-mientras compone versos, perdura a lo largo de su trayectoria poética ${ }^{28}$. Lo que varía es el tono de ese

27 PAZ, Octavio: Los hijos del limo. Barcelona, Seix, 1981, pág. 106.

28 Indudablemente Baudelaire es el punto de partida de la poesía moderna, y así se explica la atracción que sufre de Greiff. Pero al comparar sus obras se advierte que la vivencia personal y desgarrada del francés se ha convertido en el colombiano en "pose» literaria, en voluntaria devoción al modelo admirado. 
repujado rondel que aloja la mística burbuja de «un amor recatado, celeste, puro-a /modo de esos aéreos, vagos, que eternizara Poe» (Tergiversaciones, OC, pág. 92).

Edgar Allan Poe, espíritu afín a Baudelaire, es uno de los imanes que con mayor eficacia magnetizan al colombiano. La utilización de una atmósfera vaporosa, irreal, junto a nombres como Annabel, Ulalume, Ligeia, Eulalia, Leonor... confieren a la poesía una gran variedad de efectos simbólicos y alegóricos: misterio, fantasía, muerte... Los espíritus vagan en pos de la quimera, dominados por la tristeza. La Plegaria a Poe es una de las piezas degreiffianas más antologizadas:

«Oh Poe! Oh Poe! Oh Poe!

Genio del signo fatídico!

Alma que en mí domina!

Faro de luces negras!...

Acógeme en tu lóbrego

retiro de silencio.

Acógeme en tu místico

retiro de pavura...

$\mathrm{Y}$ en el retiro cándido

de tus amores puros...

Llévame a ver el cuervo

que en un país lejano

-en el país quimérico

de demonios y ángeles-

sobre el marmóreo busto,

cogitabundo y torvo,

sarcástico y sereno

mira impávido y sordo,

el dolor que en tí arde...»

(Tergiversaciones, OC, pág. 77-79)

Confïma así el poeta colombiano su voluntaria religación con Poe, personificado en ese cuervo, al que el buho degreiffiano hace eco: "Grazna el Cuervo de Poe, cabizbajo / y el Buho cifra su macabra queja» (Libro de signos, OC, pág. 119). Ese vibrar al unísono supone, no solo englobarse en una temática, sino también asumir de modo consciente la técnica del modelo; por ejemplo, Balada de Octubre aciago (Libro de signos, OC, pág. 142) comienza con tres líneas de Ulalume de Poe, que se hallan originalmente dispersas en tres estrofas diferentes del norteamericano, a modo de ritornello. De Greiff usa el mes de Octubre de la misma manera, es decir, aplica varios principios de Filosofía de la composición: el poema debe crear un efecto, intensificado con la repetición de ciertas frases a modo de estribillo, con pequeñas variantes que inciden sobre el lector... El ritmo y una versificación original dotan al poema de complejidad y sugestión ${ }^{29}$. En este camino el colombiano tiene un antecedente famoso en su compatriota Jose A. Silva.

29 No cabe duda de que E. A. Poe fue el maestro de León de Greiff, más que por los temas, por los principios del ritmo. Deudor del norteamericano, de Greiff olvida paulatinamente aplicar esos principios tan bien conocidos, alargando los poemas y dispersando el eje rítmico. Todo ello perjudicará gravemente su poesía de madurez. 
La versatilidad de León de Greiff le lleva a combinar prácticamente desde sus inicios poéticos el ambiente etéreo, crepuscular, neorromántico y pleno de sugerencias simbolistas; con la ironía, el sarcasmo y la sátira. Conviene recordar la explícita simpatía con que se acerca al poeta medieval francés François Villon, no solo en el mismo espíritu jocoso presente en las innumerables baladas del colombiano; sino también en la utilización de rondel y balada, cauces favoritos del europeo. Entroncaríamos aquí con cierta moda arcaizante y provenzalista que impuso en Francia Theodore de Banville en su Traité de metrique y en Les caprices en dixains à la manière de Francois Villon; y que parcialmente recogieron los simbolistas. Rubén Darío incluyó en su segunda edición de Prosas profanas toda una sección de Decires, layes y canciones... Ezra Pound inserta en su obra fragmentos de lírica provenzal... León de Greiff plasma el sentido de vasallaje feudal hacia la Dama; y utiliza léxico, estructuras morfosintácticas y versificación neomedievales. Lo que en otros poetas es simple moda responde en el colombiano a una cuestión de afinidad electiva con el vagabundo juglar. Ello explica el persistente influjo villoniano, como modelo literario clave, tras Baudelaire, Poe y los simbolistas. El Poema equívoco del juglar ebrio: sonata latebrante urdida en antiguo y en nuevo (Libro de signos, OC, pág. 181) ha sido inspirada por Le grand Testament de Villon, del cual cita el leitmotiv:《¿Mais où sont les neiges d'antan?» para glosar con áspera nostalgia figuras medievales desaparecidas, en la línea del ubi sunt manriqueño:

«Y del propio Villon la bizarra

odisea en medio de la hampa:

escolares, báquicos, gentuza non sancta,

reitres, mosqueteros, maestros de espada,

charlatanes, pícaros y mujeres malas,

la bizarra

odisea - ¿quién me dirá-»

(Libro de signos, OC, pág. 182)

Tal vez la lejanía cronológica permita al poeta expresar el desamparo del hombre contemporáneo, encubierto tras la ironía sarcástica que utiliza como dardo contra una sociedad a la que desprecia, pero que paradójicamente ha posibilitado su existencia.

Dentro de moldes tan dispares se va fraguando la lírica de Tergiversaciones en una atmósfera simbolista en la que me gustaría señalar dos motivos recurrentes: la noche y la luna; motivos de filiación romántica que vuelven a operar en la etapa final del modernismo: Lunario sentimental (1909) de Leopoldo Lugones; Canciones de la noche (1913) de Vicente Huidobro; Los heraldos negros (1918), de César Vallejo, y Crepusculario (1923), de Pablo Neruda, dan fe de ello sin agotar el tema. La noche es el ámbito romántico por excelencia, posibilita lo irreal, fantástico, ilusorio y despierta en el interior del poeta todo un subjetivo panorama musical, que crece embriagador en el silencio externo. Para de Greiff, la noche es algo «cósmico, grandioso y orquestal, un espectáculo polifónico de misteriosas resonancias». 
Y en la noche, la omnipresente luna, no como simple decorado sino metamoforseado en algo humano... Detrás de la mayoría de los poetas citados y de algunos más, como el mexicano López Velarde, están presentes los cuarenta y un poemas de L'imitation de Notre-Dame la Lune (1886) del simbolista Jules Laforgue. A la moda literaria se une la actualidad periodística del asunto: las primeras fotografías del hemisferio lunar visible desde la tierra son de 1896. La perspectiva científica y el deseo de desmitificar el tradicional tópico literario desembocan en el tono coloquial, desenfadado con que ahora se aborda, rayano en lo grotesco y extravagante en Lugones. De Greiff se mueve más bien en las coordenadas de Laforgue, tanto por su escritura como por la personalidad irónica encubridora de auténtica tristeza... Como Laforgue, de Greiff declara su aversión por la luz solar «que todo lo falsifica y daña» (Tergiversaciones, OC, pág. 29) y se pronuncia a favor de la superioridad nocturna en la que un paisaje geométrico y deshumanizado sugiere la falta de imaginación, la monotonía y conformidad humanas. La balada de los buhos extáticos es buen ejemplo de este primer enfoque:

«Y allí nada se vía irregular:

los bancales de forma regular

-cuadrados, cuadrados-

las regulares platabandas,

los árboles endomingados

geométricamente, conos, dados,

todo perfecto, exacto, regular...»

(Tergiversaciones, OC, pág. 27)

La esfinge lunar, fría y desolada, recibe el tributo del poeta convertido en «Pierrot lunario y decadente, / ilusorio y sentimental» (Tergiversaciones, OC, pág. 46). Los ecos de Laforgue son evidentes en este Rondel $X$, por ejemplo:

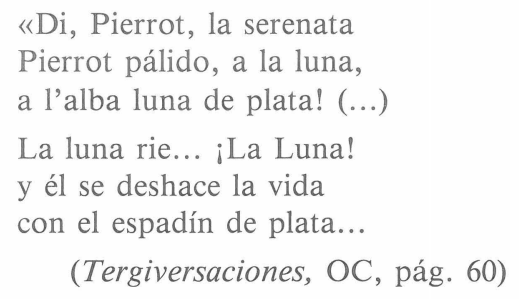

A medida que la obra del colombiano progresa, el motivo de la noche se va haciendo más y más importante e ineludible en la mágica armonía de su mundo poético. La noche y la luna experimentan diversas transformaciones, arrastrando con ellas flora y fauna constitutivas del paisaje. Con Libro de signos, (1930) entra el trópico en la lírica degreiffiana y se inicia la metamorfosis que culminará en su mejor colección poética, Variaciones alredor de nada (1936). El paisaje metalizado, geométrico, de escasos abetos y algún buho o pingüino, sólo conserva su tono gris-monotonía en la estación invernal de las lluvias. Aún así, ya se difuminan los contornos de la selva de Cauca que, con su fauna prolífica, estalla incontenible y pujante en Fanfarria en sol mayor, poema que abre la sección dedicada a Bolombolo: 
«¡Oh Bolombolo, país exótico y no nada utópico! (...)

país de sol sonoro, de excesivas palmeras, de animalillos zumbadores, de largartijas vivaces, de salamandras y camaleones, cigarras estridulantes, verdinegros sapos rugosos, y mezclados escorpiones»..

(Libro de signos, OC, 193-4)

Frente a la tórrida luz solar que «agosta las sienes del poeta como flores efímeras», la noche, enriquecida con la sugestión de las intensas plantas aromáticas y los sonidos del silencio, se personifica sensual y lujuriosa como una «morena / mujer, perfumada de nardos nupciales» (Libro de signos, OC, pág. 220), que danza para el poeta:

«Danza, Morena, Danza, mi Tanagra, mi Figulina: el sobrio cuerpo ondula: tras de tus siete velos recatada».

(Libro de signos, OC, pág. 230)

La música, el color, los aromas intensifican la atracción de la «multiforme noche». La lírica del colombiano contempla ahora la explosión de lo erótico, que se superpone al tratamiento delicado, idealista y etéreo del amor en Tergiversaciones; mediante símbolos onomásticos transforma esa Dama medieval, forma femenina imaginaria e intangible, en un ser seductor, corpóreo, trasunto de figuras eróticas de la mitología y la historia: «Calipso delirante, lady Macbeth torva, pasional Medea, aguda Xeherezada»... ser múltanime, encarnado en la noche morena con la que el poeta entabla apasionada relación:

«Juego mi vida, oh Noche, contra el abrazo perenne

de tu cuerpo moreno y felino, fogoso

o hecho ascuas de nieve!

Contra tu abrazo, oh Noche, oh Sheherezada!

oh tú, Sacerdotisa de las últimas lides,

de los ritos secretos!

Me extenuen tus besos profundos!

Me extinga entre tus brazos de terciopelo!

En tu seno amoroso me sepulte!

Y naufrague en tus ojos de sombra y de lascivia y de misterio»

(Libro de signos, OC, pág. 222)

Esta línea poética culmina en Mitos de la noche, sección de Variaciones alredor de nada que conjuga la intensidad erótica: "Yo todo me quemo en tu fuego: tu fuego / con ávidas bocas purpúreas, mi sangre y mi espíritu — goloso— se bebe» (Variaciones, OC, pág. 385); con el leitmotiv musical al que da paso La suite de la luna negra, con su ritmo cercano al «son» antillano:

«Gira

la negra,

gira

la luna, gira 


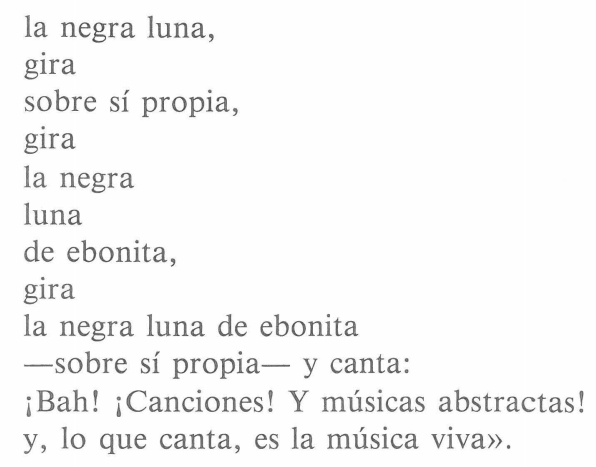

(Variaciones, OC, pág. 369)

La suite está dedicada a ensalzar una docena de sus compositores favoritos. La música penetra el pensamiento, la forma y la imagen en la poesía de León de Greiff. Músico frustado, «ama a Chopín elegíaco; a Schumann, hondo y amoroso; a Haydn, cortesano; a Frank, pulcro y místico; a Mozart, diáfano y sortílego; a Mussorgsky, angustiado y febril; a Rimsky, ebrio de luces y colores; a Debussy voluptuoso, lejano y sugerente; (...) a Wagner, la voz vigía; a Bach, añoso templo de armonía; a Schubert, rey de los alisos, reencarnación del Canto; y por encima de todos, a Bethoven, el Sordo...» ${ }^{30}$.

La producción fantástica de Wagner debe haberle impresionado porque se refiere a él más veces que a otros compositores. Por las páginas del colombiano con añoranzas vikingas, desfilan simbólicamente Tristán e Isolda, Siegfried y Brunnhilde, el Valhalla y las Valkyrias y algunos seres de la mitología escandinava y la leyenda céltica, tamizados por las óperas de Wagner. Wagner en su momento es el paradigma de la unidad de las artes, asunto caro al romanticismo, recogido por parnasianos, simbolistas, prerrafaelitas y modernismo: Darío utilizó algunos títulos como sonatina, obertura... y exploró nuevos ritmos mediante el ritornello y el tema con variaciones. De Greiff explota a fondo esta veta y lleva la proposición de Mallarmé: «De la musique avant toute chose» hasta sus últimas consecuencias. Su aportación huirá de lo melodioso como soporte del poema, tan aprovechado por los modernistas, en busca de un ritmo interno, entroncado con la música clásica. El influjo de ésta se plasma en la indicación de clave, modo y tiempo, sobre todo en sus tres ciclos de Música de cámara y al aire libre, compuestos entre 1921 y 1929 y recogidos en Libro de signos. En busca de la sintonía con el lector, indica los movimientos lentos con los términos adagio, grave, lento y serioso; un paso más rápido con andante, alegretto, alegro, vivace y scherzo...

A nivel de estructura, el poema sinfónico es una de sus contribuciones más originales a la lírica hispánica. Suele preferir formas musicales que permitan el máximo desarrollo imaginativo en la temática. El título da la pista al destinatario: preludio, fantasía y rapsodia, melodías sin restricciones formales; el nocturno, sugeridor de ensueño y fantasía; y sonata y fuga, entre las de módulo más 
fijo ${ }^{31}$. Su corpus poético incluye unas catorce obras tituladas sonata, que se estructuran en tres movimientos: 1.- Una exposición, por ejemplo, en la Sonata de 1914:

«La noche canta: rima...!

El jardín glosa: sueña...!

La luna dice: ama...!

(Tergiversaciones, OC, pág. 65)

2.- Un desarrollo imaginativo de temas relacionados con los propuestos en la exposición - aquí, la fuente, la amada, la vida...-; para llegar en el 3.- a una síntesis de los elementos iniciales que se recogen, enriquecidos:

«La noche dice el verso de la vida, la fuente canta el canto de la vida la luna sueña el sueño de la vida: y la amada es la vida».

(Tergiversaciones, OC, pág. 66)

En cuanto a la fuga, menos utilizada por el maestro, lo importante es el contrapunto de voces entretejidas sobre un tema expuesto al principio. Se acerca al tema con variaciones y al rondó, en que el tema se va reiterando con nuevas implicaciones después de cada episodio. El variante melódico del sinfonismo se imita mediante la repetición de tema o frase, a modo de estribillo que puede ser alterado; y aprovechando las cualidades aliterativas, onomatopéyicas y rítmicas del idioma, que casi indefectiblemente potencian la rima consonante, indispensable para el simbolista de Greiff. Por este camino hay un deslizamiento progresivo hacia la intensificación rítmica; hasta el punto de supeditar la invención léxica, lo semántico y la misma estructura versal a conseguir determinados efectos de ritmo. Es el caso de múltiples pasajes de oscuro significado: «engibacaires, abderitanos, macuqueros»... (Variaciones, OC, pág. 396), o de tono especialmente alado: «siga, siga la danza, siga / la zarabanda la tarantela, siga la giga»... (Variaciones, OC, pág. 409). En la poesía del siglo XX — dice Friedrich- las palabras son «líricas formas sonoras que dejan tras de sí una estela de fascinación» ${ }^{32}$.

Así se explica también la evolución métrica de la poesía del colombiano, desde la aplastante mayoría del soneto, —endecasílabo o alejandrino, con axis rítmico isopolar - en Tergiversaciones y la primera parte de Libro de signos; hasta el verso libre que triunfa en Variaciones alredor de nada. Su melodía se apoya en enumeraciones escalonadas, a base de artículos, conjunciones y preposiciones; o incluso nombres propios y verbos de acción que se reiteran. Hay que añadir encabalgamientos suaves, con el fin de desdibujar las fronteras entre verso y prosa poética. El deseo de experimentación rítmica y la fantasía desenfrenada que se va adueñando paulatinamente de su obra, determinan la alternancia de una

31 Como excelente músico que es, la aplicación de términos musicales es bastante seria, y normalmente la fusión de las artes es de lo más conseguido en su poética.

32 FRIEDRICH, Karl: La estructura de la lírica moderna. Barcelona, Seix, 1974, pág. 257. 
métrica rigurosa y formal; con otra más abierta que mezcla diversos tipos de rima y metro en cada poema, o contribuye - como hicieron los modernistas - a desintegrar desde dentro la estructura clásica del soneto por medio de una configuración rítmica heteropolar. De tal modo, se pretende apoyar el carácter tenso o la expresión conmovida con pausas versales en los extremos y recursos gráficos puntos suspensivos, guiones, rayas, interrogación...

Expuestas aquí las líneas maestras de su poética, quedaría enfrentarnos a una cuestión fundamental: el peculiar León de Greiff, ¿puede considerarse vanguardista? En el entorno colombiano, provinciano y conservador, indudablemente actua como disolvente corrosivo; pero sus aportaciones son limitadas y se mueven en la onda de la estética simbolista. Hay que reconocer que la mayoría de los Nuevos fueron ajenos a la poética de vanguardia. Hechos de notoria importancia se suceden durante estos años: Apollinaire y sus Calligrammes; Le Cimetière marin de Valéry; Trilce, de Vallejo y el Neruda de las Residencias; la rebelión surrealista en 1924; el ultraismo, creacionismo y los movimientos de vanguardia europeos y americanos; las discusiones en torno a la poesía pura del abate Bremond a partir de 1925; el centenario de Góngora en 1927... Fueron años invadidos de teoría poética y de polémica sobre la lírica moderna. Casi nada de ello se escuchó en Colombia, que siguió viviendo con el tradicional desfase respecto de los movimientos poéticos contemporáneos. Así el influjo de Góngora y el resurgir del soneto y la tradición hispánica llegan de la mano de Juan Ramón Jiménez al final de la década del treinta con la generación de los piedracelistas (Jorge Rojas, Eduardo Carranza, Tomás Vargas Osorio, Arturo Camacho Ramírez) y se continúa en los cuarenta con la generación de Cántico, que toma como guía a Jorge Guillén.

Con este trasfondo, el extremo subjetivismo de León de Greiff hace que su obra más que original, sea casi única. Frente a la poesía comprometida mantuvo la convicción de que el fin de la lírica es crear un lenguaje dentro del lenguaje. La poesía es experiencia física de la palabra, hasta llegar a sustituir con ella la mezquina realidad cotidiana. Por aquí conecta con las teorías creacionistas del Non serviam de Huidobro. La riqueza y variedad de su léxico, y los incesantes juegos de palabras en pro de la experimentación lingüística, le acercan a la destrucción del lenguaje de Altazor. Ciertas reminiscencias surrealistas afloran en el gesto altivo e insolente del poeta y en su apelación al mundo de los sueños. Pero su escaso interés por el hombre y la sociedad que le rodea le aleja de la beligerancia política de Bretón.

Habrá que esperar a la generación de Mito (1955-1962) para establecer desde la poesía un diálogo crítico con el mundo colombiano y abrir las puertas al pensamiento hispanoamericano y europeo más avanzado; actitud que intensificarán los nadaistas en la década del sesenta. Será entonces cuando triunfe la imagen surrealista, el lenguaje coloquial en lo poético; y la actitud provocativa frente a la sociedad. Hasta ese momento la figura de León de Greiff permanecerá como la del poeta discordante, emparentado con los moldes simbolistas, que abrió en su país la marcha hacia la vanguardia, entendida como un común ademán sedicioso, un gesto inconformista e independiente. 
